\title{
The tragedy of the water commons: the case of the Lower Orange water management area
}

\author{
CM Gouws
}

\begin{abstract}
In the human environment there is a tendency to refer to resources, such as land and water which do not specifically belong to any single individual, as the 'commons'. Garret Hardin wrote his famous paper called: "The Tragedy of the Commons" in which he highlighted the problem inhabitants of the world face regarding the growing population and depletion of natural resources. He proposed that limits must be placed on the liberal use of natural resources, which usually involve some kind of legislation. South Africa, as a semi-arid country, needs to manage the water as a commons to ensure that all inhabitants of the country have access to safe drinking water as instructed by the Constitution of the Republic of South Africa Act No. 108 of 1996 and subsequently preserved in the National Water Act No 36 of 1998. The significance of Hardin's theory to South Africa becomes evident in the necessity of the mentioned acts, which involve the establishment of Catchment Management Agencies (CMAs) and Water User Associations (WUAs). These institutions must ensure the involvement of all stakeholders and water users to manage the resource optimally. Establishing these institutions, however, proved to be difficult and their efficiency questioned, thus illustrating a "tragedy within the tragedy". This article considers the case of the Lower Orange Catchment Management Agency and the Upington Islands Water User Association in the //Khara Hais local municipality, to illustrate the thus far failing efforts taken by this region to manage the water resource.
\end{abstract}

Keywords: Lower Orange River Management Area, Catchment Management Agency, // Khara Hais, water user association, department of water affairs and fortestry (DWAF), integrated water resource management (IWRM), tragedy of the common.

Disciplines: Political studies, Public management and governance.

Ina Gouws is a lecturer in Political Science, School of Basic Sciences, NorthWest University, Vaal Triangle Campus, South Africa. Email: ina.gouws@nwu.ac.za The article is based on her research for $\mathrm{PhD}$ on the water management in the Lower Orange River catchment, specifically in the Khara Hais local municipality. 


\section{Introduction}

With current population pressure, the world needs solutions to provide its human inhabitants with basic natural resources to secure the survival of humanity. One of these resources is safe drinking water. The sustainability of this resource seems to provide countries with the most headaches, and they usually look to science and technology to find solutions to this problem. In this paper, a theory to solving the over population problem will be explored, namely: The Tragedy of the Commons. The core of this theory is stated in a quote by its creator, Garrett Hardin:

The population problem has no technical solution; it requires a fundamental extension in morality. ${ }^{1}$

As discussed in section two of this paper, the morality of a society, be it global or in the form of nation state, seems to manifest in legislation and policy and in how these are implemented. Access to safe drinking water is protected in the Constitution of the Republic of South Africa Act, 108 of $1996 .^{2}$ The challenge has been to provide this access and to manage water resources effectively. Subsequent water legislation, as well as planning frameworks, such as the National Water Act, 36 of $1998^{3}$ and The National Water Resource Strategy ${ }^{4}$ attempt to address the national need to supply water to all people resident in the state. The legislation and the provision for institutional development it presents, is discussed in section three and four of this article and illustrates that South Africa developed sound legislation to arrange the tragedy of the commons. The practical implementation of this legislation and management strategies is discussed in section five, with an investigation into the development of the Lower Orange Catchment Management Area (LOCMA) and the Upington Islands Water User Association (UIWUA). This is a semi-arid, water scarce area and the effective management of the water commons is essential for the survival of inhabitants of this area, whether their requirements are for domestic use, irrigation or industry. An investigation was conducted into the efforts of the Department of Water Affairs and Forestry (DWAF) in this region, as well as relevant stakeholders responsible for establishing the Lower Orange Catchment

1 G. Hardin," The Tragedy of the Commons". Science, New Series, Vol. 162(3859), 1968. pp. 1243-1248.

2 Republic of South Africa (1996). The Constitution of the Republic of South Africa, Act 108 of 1996, Pretoria: Government Printer.

3 Republic of South Africa (1998). The National Water Act, 36 of 1998. Pretoria: Government Printer.

4 Republic of South Africa, Department of Water Affairs and Forestry. 2002. National Water Resource Strategy; Summary. 2002, Pretoria: Government Printers. 
Management Area (LOCMA) and the Upington Islands Water User Association (UIWUA). Semi-structured interviews were held with relevant individuals to establish what has been done to develop and establish these institutions, what the problems are that they faced and the degree of success that was achieved thus far.

The objective of the paper is to highlight the relevance of "the tragedy of the commons" in the necessary development of institutions to manage the available water resource in the LOWMA to prevent depletion of the resource. This study also highlights the "tragedy within the tragedy" that manifests when these institutions fail to effectively manage the water resource.

\section{The tragedy of the commons}

The first order of business is to explain what the "commons" is. Those resources that are consumed by all inhabitants of the world, like water, air and land, are referred to as the commons. The understanding is that the commons will always be enough to sustain everyone as long as each only takes his share. The depletion of the commons started when everyone started to consume more than their share. To prevent the complete depletion of the commons, restrictions needed to be put in place for the use of the commons. For land, private ownership became a likely solution. Water on the land also became "privately owned". This meant that the owner could for instance have a water well on the property and use the water freely. If the well dried up, it was the owner's problem to solve. The more inhabitants consumed the water resource freely and without real consequence, the more the resource turned out to be in short supply. ${ }^{5}$

Hardin highlights the concern with the concept of a class of human problems which cannot be solved by means of technical solutions. ${ }^{6}$ One of the members of this class is the "population problem". He argues that most people, who anguish over the population problem, are generally individualists. They cherish individualism because it creates freedom. Individualists see freedom as a gift. But in this context, the gift is threatened because the more the population surpasses the capacity of the environment, the more freedoms have to be sacrificed.

The tragedy of the commons can also be explained as a social trap that involves a conflict over resources between individual interests

5 G Harding, The commons, 1997, (available at: http://members.aol.com/trajcom/ private/commons.htm, as researched on 14 September 2007.)

6 G Hardin, "The tragedy...." Science, New Series, Vol. 162(3859), 1968. pp. 12431248. 
and the common good. ${ }^{7}$ It takes place when there is an inclination towards free access and unrestricted demand for a limited resource. Hardin argues that population has a natural tendency to maximize, meaning to "to achieve the greatest good for the greatest number". ${ }^{8}$

Merely surviving is simply not good enough. The population wants to consume as much as possible for maximum enjoyment. The problem is that resources that are consumed are not maximized as well. The population grows, but natural resources, like drinking water, do not. They become exhausted. At a moment in time, the realization dawns that the current consumption of the natural resource will not sustain the population indefinitely. So, to avoid depletion of this natural resource, population must show zero growth. Not one population in the world can show zero growth although most developed countries show a drop in their population growth rates. The current world population growth rate steadily declined from $2.3 \%$ per annum during the period of 1963/64 to $1.2 \%$ per annum in 2008 as indicated by the United States Census Bureau. ${ }^{9}$ Most developing countries in Africa, excluding South Africa, show rather the opposite. According to Gaisie ${ }^{10}$, the population growth in sub-Saharan Africa increased from $2.2 \%$ per annum in 1950 to $3.4 \%$ per annum in 2000 . The South African population growth rate declined steadily from $1.5 \%$ per annum in 1995 to $1 \%$ in $2007 .{ }^{11}$ Reasons for this growth differences are the impact of AIDS on mortality rates in South Africa according to the United Nations World Population Prospects, the 2006 revision. ${ }^{12}$ This report also mentions that the decline in population growth in South Africa will likely be nullified by the hordes of immigrants (legal and illegal) flocking to South Africa from poorer African countries, putting a strain on the nations' resources.

Hardin proposes that there is no technical solution to this problem,

7 ANON. "Tragedy of the Commons", Wikipedia, the free encyclopaedia. 2007 (available at : http://en.wikipedia.org/w/index.php?title=Tragedy_of _the_commons, as researched on 11 July 2007).

8 G Hardin, "The tragedy...." Science, New Series, Vol. 162(3859), 1968. pp. 12431248.

9 The U.S. Census Bureau International Data Base. World Population Information. Updated 28 July 2008 (available at: http://www.census.gov/ipc/www/idb/ worldpopinfo.html, as researched on 28 July 2008).

10 SK Gaisie, "Demographic transition: the predicament of sub-Saharan Africa". Health Transition Review. Supplement to Volume 6, (1996). pp. 345-349.

11 Republic of South Africa. Statistics South Africa. Mid-year population estimates 2007. Statistics South Africa: Pretoria. 11 p.

12 United Nations. Department of Economic and Social Affairs. World Population Prospect, the 2006 Revision Highlights. 2006 (available at: http://www.un.org/ esa/population/publications/wpp2006/WPP2006_Highlights_rev.pdf, as researched on 28 July 2008). 
but that basic morality should be extended to find solutions. ${ }^{13}$ However, De Young argues, that not all commons will suffer the same fate. He argues that there must be a distinction between a public good and a commons. ${ }^{14}$ This distinction is related to the subtractability of the resource as explained by Ostrom. ${ }^{15}$ Subtractability refers to whether an individual's consumption of a resource deprives others of using it. If one's consumption of a resource does not deprive others of using it, it is not a commons, but a public good. Public good resources can be certain crops being consumed with individuals allowing each other access to consumption without reservation, especially since in most of these cases; consumers are not contributing to caring for theses crops. A commons, on the other hand, like water, is the kind of resource that all individuals contribute in maintaining and consuming, making it possible for this resource to be overused. As such, individuals tend to care very much who gets to use it and how much is being used. An additional distinction, highlighted by Feeny, is the issue of access to a resource. ${ }^{16}$ In this instance, the tragedy occurs when the necessary restrictions needed to be put in place to conserve the commons, is too costly or does not work. Feeny refers to this phenomenon as "the tragedy within the tragedy", meaning that it is a tragedy that the water commons needs to be managed which results in restricted access to the resource, but that a tragedy WITHIN this tragedy occurs when these management strategies fail. Under these circumstances the water commons remains in danger of being depleted. This important distinction by Feeny is emphasised in the example of the Lower Orange discussed later in this study.

Ultimately, the moral responsibility lies in the recognition that natural resources, like water, are common. Only then do we acknowledge the fact that they require management. Various restrictions, like legislation, are then introduced to place limit the use of this resource. It takes away a sense of freedom of individuals. However, it is important because it will ultimately preserve and nurture other freedoms. Complete freedom will only lead to tragedy. Herein rests the tragedy of the commons. By developing legislation to manage the water resources on the planet, global organizations and governments alike,

13 G Hardin, "The tragedy...." Science, New Series, Vol. 162(3859), 1968. pp. 12431248 .

14 R de Young, "Tragedy of the commons". 1999. In Alexander, D.E. \& Fairbridge, R.W. [Eds.] Encyclopedia of Environmental Science. Hingham, MA: Kluwer Academic Publishers.

15 E Ostrom, "Governing the Commons: The Evolution of Institutions for Collective Action". (1990). New York: Cambridge University Press, p.32.

16 D Feeny, et al. 1990. The tragedy of the commons - 22 years later. Human Ecology, v. $18,1-19$. 
will restrict the consumption of the resource, which may take away certain freedoms, but will preserve other freedoms like life itself. The tragedy of the commons, as a water management theory, can as such, have an important influence on water management. To manage natural resources, like water, an understanding of the complex connection of global, national and local management regimes within a rapidly developing economic, political and institutional transformation is necessary. South Africa seems to have made sufficient plans to prevent the tragedy of the commons with admirable water legislation and management strategies developed since 1998. The legislation aims to prevent unrestricted access to and better manage the country's scarce water resources. As is the case in most other states of the world, the concept of Integrated Water Resource Management (IWRM) is used as a blueprint to formulate legislation and policy strategies to effectively manage water resources.

World-wide, Integrated Water Resource Management (IWRM) is regarded as the most efficient manner in which the basic water needs of consumers can be met. ${ }^{17}$ It emphasises the maxim: more for all, instead of much for few. IWRM is a key component of integrated water provision, which in turn is a condition of sustainable development. DWAF defines IWRM as a strategy (policy) that influences the need and usage of water in order to ensure sustainability of the water. ${ }^{18}$ Thus, IWRM focuses on the manner in which water is used rather than simply supplying the demand for water, in order to reach the following goals: economic efficiency, social development, social equity, the conservation of the environment, sustainability of water supply and political acceptability. ${ }^{19}$ This focus of IWRM, directly address the problems highlighted the tragedy of the commons. To prevent the depletion of the water commons, restrictions to open access to the resource need to be put in place, thus ensuring the above mentioned objectives.

A paradigm shift from the traditional supply-oriented view to that of water conservation and demand management is necessary for the sustainability of water resources. This is crucial for the environment as well as for economic efficacy and social development. The shift

17 A Turton, Water Demand Management Programme for Southern Africa: Phase II. Analytical Paper: the problematique of WDM as a concept and a policy: towards the development of a set of guidelines for Southern Africa, 2002, (available at: http: / / www.up.ac.za/academic/libarts / polsci/awiru/papers / op43/op43.html, as researched on 10 July 2007).

18 Republic of South Africa. Department of Water Affairs and Forestry 1991. National Water Conservation and Demand Management Strategy Framework. Pretoria: Government Printer. 50p (WBP-1991)

19 A Turton, "Water Demand..." Management at: http://www.up.ac.za/academic/ libarts/polsci/awiru/papers/op43/op43.html, as researched on $10 \mathrm{July} \mathrm{2007).}$ 
towards this integrated approach is a long-term process and requires active effort and commitment from all stakeholders and role-players on various levels in the institutional and political arena. ${ }^{20}$ The following sections will introduce how South Africa's National Water Act No. 36 of 1998 and how the National Water Resource Strategy intends implement IWRM to ensure equal access and to put restrictions in place to preserve water as a commons.

\section{The National Water Act No. 36 of 1998}

The National Water Act No. 36 of 1998, emphasises the new democratic dispensation and gives effect to the constitutional right of access to water. Section 27 of the Act clearly states that each individual has the right of access to sufficient water and food. ${ }^{21}$ In principle the Act determines that water is a national resource and that it is owned by the inhabitants of South Africa, but that national government acts as the trustee, or custodian, of the resource through the minister of water affairs and forestry. The purpose of the Act is therefore essentially to ensure that the county's water resources are protected, utilized, developed, conserved, managed and controlled. This principle makes evident the idea that the water resources in South Africa are seen as a commons for all inhabitants of the country. They have access to it, but they available supplies need to be protected and managed by government to avoid depletion. Thompson cites a few criteria to be considered when pursuing these objectives. They include:

- meeting the basic human needs of present and future generations;

- promoting equitable access to water;

- promoting efficient, sustainable and beneficial use of water in the public interest;

- facilitating social and economic development;

- providing for growing demand for water use;

- reducing and preventing pollution and degradation of water resource; and

- meeting international obligations. ${ }^{22}$

20 A Turton, Water Demand Management.........(available at: http://www.up.ac.za/ academic/libarts/polsci/awiru/papers/op43/op43.html. as researched on 10 July 2007).

21 Republic of South Africa (1998). The National Water Act, 36 of 1998. Pretoria: Government Printer.

$22 \mathrm{H}$ Thompson, Water Law. A practical approach to resource management and the provision of services (2006), Cape Town: Juta and Co Ltd. 
By attending to these aspects, implementing the Act should enhance IWRM. This could, for example, be done within the framework of catchment management strategies and establishing suitable organisations, like Water Use Associations (WUAs). The Act provides for the establishment of 19 catchment management agencies, each with its own area. Each agency must develop a management strategy for its area and must perform important functions in terms of the application of the Act. ${ }^{23}$

\section{Figure 1. The nineteen catchment management areas identified by DWAF. ${ }^{24}$}

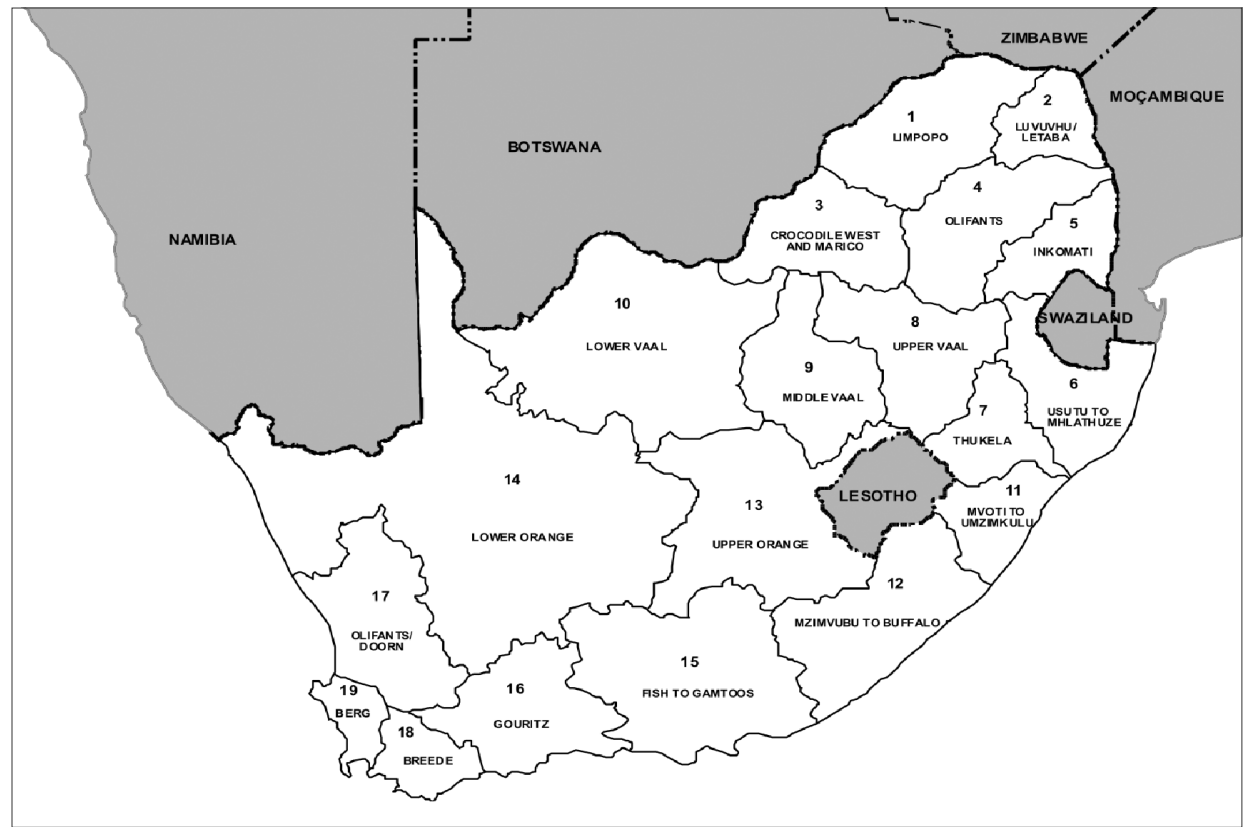

These agencies actively encourage community involvement and try to eliminate conflict between the stakeholders. The Act provides for the creation of associations by the stakeholders in order to encourage sensible water use. This clause is important since it regulates relations between the consumers and the agencies with the purpose of effectively regulating and managing water resources. ${ }^{25}$ The idea is

23 Republic of South Africa, The National Water Act...,1998, Pretoria: Government Printer.

24 Republic of South Africa, Department of Water Affairs and Forestry. 2002. National Water Resource Strategy, 2004. Pretoria: Government Printers. p. 94.

25 Republic of South Africa, The National Water Act...,1998, Pretoria: Government Printer 
that national government remains in control of water resources, but that stakeholders are involved in the management of the resource through catchment management agencies. ${ }^{26}$ IWRM therefore takes place by encouraging all those involved to decide together on grassroots-level about how much water should be allocated where and in which manner.

To achieve these goals, the National Water Resource Strategy (NWRS) was developed. This strategy takes the division of the 19 management areas provided for in the Act and provides a management strategy for each by taking into account the extent of the water commons in each, what the resource is used for and how it should be developed.

\section{The National Water Resource Strategy}

The National Water Resource Strategy (NWRS) binds all water institutions and water users and must be updated at least every five years. The NWRS provides practical structures to manage water resources and to establish relevant institutions, like catchment management agencies. ${ }^{27}$ According to DWAF, the main purpose of the NWRS is to:

- facilitate the proper management of the nation's water resource;

- provide a framework for the protection, use, development, conservation, management and control of the water resource of the country as a whole;

- provide a framework within which water will be managed at a regional or catchment level, in defined water management areas;

- provide information about all aspects of water resource management; and

- identify water-related development opportunities and restraints. ${ }^{28}$

The NWRS identifies prospects where water can be made accessible for productive livelihoods, and the sustainability and support needed to use the water efficiently. ${ }^{29}$ In fulfilling their functions, the agencies are required to actively promote community participation. However,

26 Republic of South Africa, The National Water Act....,1998, Pretoria: Government Printer

27 Republic of South Africa, Department of Water Affairs and Forestry. 2002. National Water Resource Strategy; Summary. 2002, Pretoria: Government Printers.

28 Republic of South Africa, National Water Resource Strategy.......,2002, Pretoria: Government Printers.

29 Republic of South Africa, Department of Water Affairs and Forestry, Internal Strategic Perspective: Lower Orange Water Management Area, 2004, Pretoria: Government Printers. 
such facilitation will prove difficult considering the large size of most of the catchment management areas. This issue points to the tensions existing between close interaction with water users, on the one hand, and financial viability, holistic management of the whole catchment, and the potential for cross-subsidisation, on the other. Most significantly, the effectiveness of stakeholder involvement will depend on the interactions between the agencies and voluntary associations of water users. The NWRS provides for such associations to be formalized as water user associations and catchment management agencies. The purpose of a catchment management strategy is to:

- set principles for allocating water to existing and new water users;

- provide a framework for managing water resources within the water management area;

- ensure that the water resources within the water management area are protected, used, developed, conserved, managed and controlled. ${ }^{30}$

These strategies must clearly communicate the intention of agencies in its dealings with the water resources in the water management area and how these resource will be managed.

The department of water affairs and forestry (DWAF) defines a catchment management agency (CMA) as a statutory body, which means that its establishment is approved by means of a formal government notice. It is a governing board, appointed by the minister. The minister acts, through DWAF, to delegate water resource management to the regional and catchment level. ${ }^{31}$

30 T O' Riordan, R Preston-Whyte, R Hamann, M Manqele, "The transition to sustainability: A South African perspective. South African Geographical Journal, 82(2), 2000, pp. 1-10.

31 Republic of South Africa, Department of Water Affairs and Forestry, Establishing a Catchment Management Agency, Guide 2 in the CMA/WUA series, 2005. (available at: http://www.dwaf.gov.za/CM / Docs/WORD/ Guide2final\%20version4.doc, as researched on 15 November 2007). 


\section{Figure 2: Illustration of the hierarchy of minimum required personnel in establishment of a CMA as identified by DWAF. ${ }^{32}$}

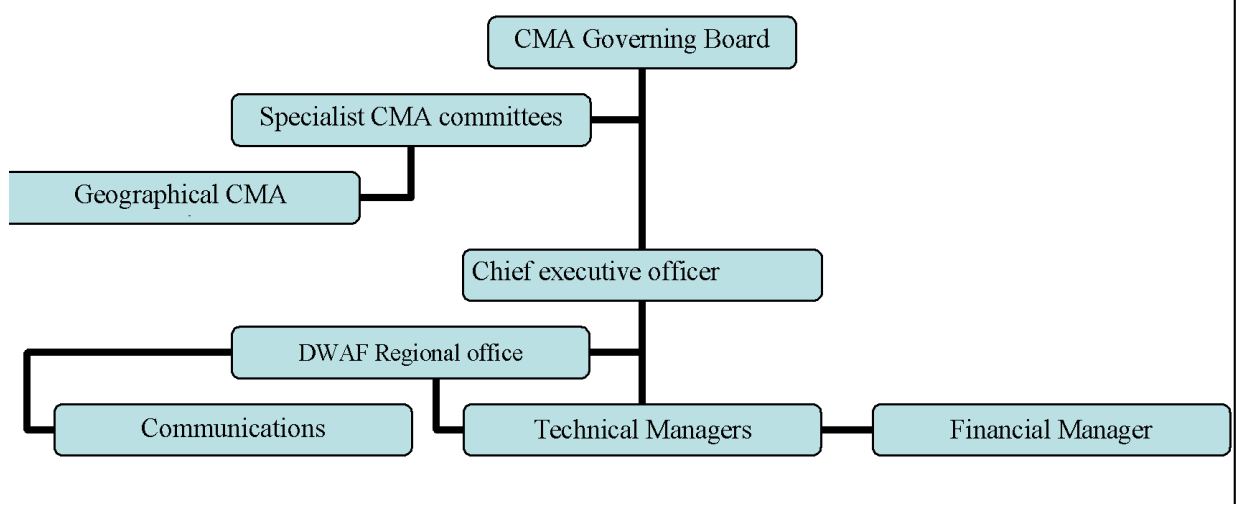

The main purpose of a CMA is to involve local communities in water resource management. A CMA must ensure that all interested parties in particular also the previously disadvantaged communities must be included in decisions regarding management of the water resource. There are four major role players in establishing a CMA. Firstly, DWAF is the body responsible for the process to adhere to the requirements of the National Water Act No. 36 of 1998. Secondly, other statutory water bodies that are playing a role in water management, like the Upington Irrigation Board in the / / Khara Hais local municipality which is in the Lower Orange Catchment Management Area. Thirdly, stakeholders and water users play a role. These will typically be local residents and irrigation farmers in this area. Lastly, local, provincial and national government play a role. The CMA must in the end be able to encourage cooperative government between these levels of government. ${ }^{33}$

\section{The Lower Orange Water Management Area}

The LOWMA has more or less the same borders as the northern frontier of South Africa's Northern Cape Province.

32 Republic of South Africa...Establishing a Catchment Management Agency... 2005.

33 Republic of South Africa, Department of Water Affairs and Forestry. CMA Proposal Development, 2001. (available at: http://www.dwaf.gov.za/CM/Docs/WORD/ Preproposal_CMA_Doc1.doc, as researched on 16 November 2007). 


\section{Figure 3: The Lower Orange Water Management Area ${ }^{34}$}

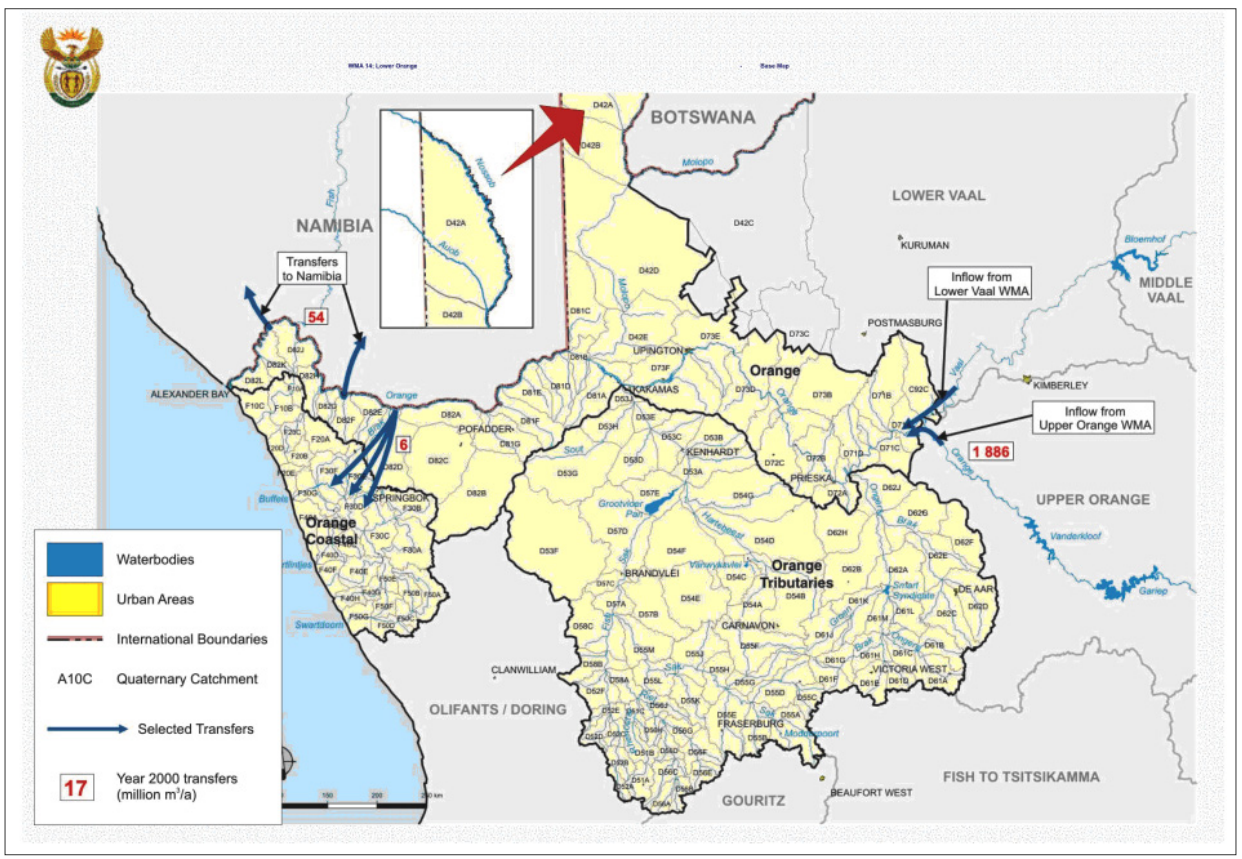

The LOWMA is a section of the comprehensive Vaal and Orange River Systems. It is a semi-arid region with low rainfall and an almost desert-like climate. Water is mainly used for domestic use, industry and especially, irrigation. The main source of water for this management area is the section of the Orange River that flows through the Northern Cape. The Orange River is also the border between South Africa and Namibia.

According to DWAF this surface water source is not nearly enough to support existing development in this Water Management Area (WMA). About $93 \%$ of all water in the Orange River is generated upstream of the Vaal/Orange convergence. This means that the manner in which the water source upstream is managed in other WMAs, has an influence on what ends up in the Orange River. The Orange River supports large scale irrigation in its alluvial soils along the Orange River valley. ${ }^{35}$ The total available water component in the LOWMA is 1122 million $\mathrm{m}^{3} / \mathrm{a}$ and this includes groundwater.

34 Republic of South Africa, Department of Water Affairs and Forestry. Bitmap of the Lower Orange Water Management Area (available at: www.dwaf.gov.za/ Documents/Other/WMA/14/LowerOrangeISPJul04Adp.pdf, as researched on 14 May 2008). 
Groundwater is in most cases the only available water source in the LOWMA. It is mainly used for domestic use and livestock watering inland away from the river. It is not enough to support any large scale irrigation. The water used for irrigation is mostly surface water from the Orange River.

Further development of the groundwater resource close to the towns is not possible. Investigating groundwater potential outside town seems to be the only option. ${ }^{36}$ It is thus clear that the water source (the commons) needs to be managed to ensure that all inhabitants get their fair share. To do this, the LOCMA needs to be established.

The LOCMA (not) managing the water commons

Establishing the Lower Orange Catchment Management Agency (LOCMA) was planned as medium-term process in 2001. The process was scheduled to be in place by $2007 .{ }^{37}$ The following section describes the efforts to establish the LOCMA. Although public participation as a requirement for the establishment of the LOCMA is emphasised, the focus will fall on the responsibilities of DWAF officials who are responsible for getting the process going and ensure sustainable progress with the establishment of the LOCMA as the eventual goal.

The LOCMA, like all other catchment management agencies can only be established once the governing board is appointed. During the process of getting the LOCMA established, activities had to go on according to the Internal Strategic Perspective (ISP). This document represents DWAF's view on how Integrated Water Recourse Management (IWRM) should be introduced and put into effect. An ISP provides a framework to DWAF's management of each water management area until it is possible to hand over the management functions to the established Catchment Management Agency (CMA). DWAF identifies a few functions that CMAs must adhere to:

- investigate and advise on the protection, use, development, conservation, management and control of the water resource in the water management area;

- develop a catchment management strategy;

- coordinate activities of water users and water management

35 Republic of South Africa. National Water Resource Strategy...., 2004, Pretoria: Government Printers

36 Republic of South Africa, National Water Resource Strategy...., 2004, Pretoria: Government Printers

37 E-mail correspondence, B Conradie, (conradb@dwaf.gov.za) 2004. Discussion on water demand management in Lower Orange Catchment Management Area. [Email to:] Gouws, CM (pwscmg@puknet.ac.za). Jul. 27 
institutions;

- promote coordination between implementation of catchment management strategy with implementation of water services development plans by water services authorities (municipalities);

- promote community participation in the protection, use, development, conservation, management and control of the water resource in the water management area. ${ }^{38}$

In addition to adhering to these requirements, the CMAs, and the ISPs, are supposed to ensure consistency when responding to requests for new water licenses, and informing water users on how DWAF will manage the water resource within the area of concern. ${ }^{39}$

In the LOWMA the process progressed as follows: At a planning session held by DWAF in the //Khara Hais municipal district (Upington), on 5 September 2002, the Directorate of Catchment Management planned for the establishment of the LOCMA. The target date for the LOCMA establishment proposal was April 2006. The proposed date to establish the LOCMA governing board was determined to be April 2007. ${ }^{40}$

It was emphasised how important it would be to create an awareness of the processes that followed. The public had to be informed on the progress that was made. Public participation, it was decided, would be invaluable in the process of establishing the LOCMA. Stakeholders had to be identified; stakeholder needs had to be identified; and capacity building and empowerment of stakeholders had to be dealt with. The important issue of empowerment implied that knowledge had to be transferred from DWAF the leaders of different stakeholder groups. They had to become "water literate". It was found that major stumbling blocks in the process would be water services, poor communication as well as confusion about tariffs. ${ }^{41}$

An essential planning component that emerged from the deliberations was that, it should not be DWAF that takes the initiative to draft the proposal for establishing the LOCMA. Thus, maximum participation from all stakeholders was a prerequisite in the process of drafting the proposal. The envisaged ideal was for a drafting team

38 Republic of South Africa. Department of Water Affairs and Forestry, Guide to the National Water Act (no. 36 of 1998)-Part 2: Water Management Strategies, 2006. (available at: http://www.dwaf.gov.za/Documents/Publications / NWAguide/ part2.pdf, as researched on 15 November 2007).

39 Republic of South Africa, National Water Resource Strategy...., 2004, Pretoria: Government Printers

40 E-mail correspondence, B Conradie - CM Gouws, Jul. 27, 2004TD, 4(1), July 2008, pp. 31-59.

41 E-mail correspondence, B Conradie, Jul. 27,2004 
to be assembled from the overall Lower Orange water management area. They had to initiate discussions, deliberations and formulate the proposal. The main functions on the side of DWAF were to process design and planning, develop communication and to evaluate the process. DWAF also had to provide feedback to all functions that were to be performed by the department. External stakeholders were to provide administrative support to ensure a complete and accurate record of public participation towards LOCMA establishment. The timeline decided upon during the above mentioned planning session were as follows: In 2003, all efforts were made towards creating public awareness with all stakeholders in respect of water management issues. Inhabitants of the area were to be introduced to the concepts of catchment management and water user associations. During this time sub-catchment forums were to be established to ensure public participation and a consultation process was to be adopted to include all stakeholders. In 2004 a steering committee was to be established to ensure that planned processes are followed through. In 2005 the proposal to the minister for establishment of the catchment management agency was to be initiated. In 2006 the proposal was to be sent to the minister and ultimately approved by the minister. The governing board of the catchment management agency could then be established which would have led to the final establishment of the LOCMA in 2007. ${ }^{42}$

The activities planned for during this planning session did not take place as planned. ${ }^{43}$ The first point in the strategy decided upon in 2002, was that DWAF should not take the initiative to develop the draft proposal to establish the LOCMA. In practice, the DWAF office in the region had to take initiative to get the process started since strategies to get the public involved, failed in the beginning. ${ }^{44}$ This meant that the strategies decided upon in the planning sessions in 2002 were not followed right from the start. In 2007 the steering committee was still not formalised and the proposal to the minister not initiated. Several reasons for this were given by Mr Kubayi, director of catchment management in the LOWMA. ${ }^{45}$ He stated that the previous director's resignation in 2006 disrupted the process. She was an integral part of the process, especially in respect of public participation. Mr Kubayi himself was only appointed in June 2006 and was still in the process of learning what precisely constituted the plans of action and the required procedures. A major problem was also the problems he faced with regards to communication with the community. He was not proficient in Afrikaans, the language

42 E Kubayi (Personal Collection), interview CM Gouws, 7 November 2007.

43 The repetition of "planned" was deliberate!

44 E-mail correspondence, B Conradie, Jul. 27, 2004

45 E Kubayi (Personal Collection), interview CM Gouws, 7 November 2007. 
spoken by most inhabitants in the LOWMA. Furthermore, DWAF moved the deadline for establishment of the CMA from 2007 to 2011. The department currently is in the process of reprioritising the establishment of CMAs across the country. The LOCMA will be last to be established.

The most explicit reasons identified for the failure of this institution to get established and perform its functions are as follows:

- The slowing down of the process of establishing the LOCMA by DWAF. The department set a new due date for 2011 - last on the list of DWAF after reprioritising the establishment of Catchment Management Agencies.

- Human resource turnover is problematic. Individuals, who started the process, left the employment of DWAF before the process was completed. New personnel have to familiarise themselves with the procedures of what was done, what needs to be done and most importantly, how it needs to be done.

- The DWAF office in the LOWMA experiences difficulties to retain trained technical experts to manage infrastructure.

- Communication problems are hampering the process. Afrikaans is the language most spoken by inhabitants of the LOWMA and DWAF appoints personnel who cannot speak the language. This is especially problematic in the rural areas where inhabitants do not understand English very well, and as such do not retain important information relayed to them regarding the LOCMA. As a result, public participation is not at the levels it should be to validate the establishment of the LOCMA.

The problems encountered by the LOWMA in establishing the necessary institutions as required by legislation, proves the distinction of the tragedy WITHIN the tragedy identified by Feeny ${ }^{46}$ earlier this article. In the case of the LOCMA, the tragedy WITHIN the tragedy is that the LOCMA as water management institution is supposed to manage the water commons in the LOWMA. The institution is however not working as it should, thus not doing what is required to protect the water commons. The same can be said for the problems facing the Upington Islands Water User Association.

\section{The Upington Island Water User Association}

A Water Use Association (WUA) is a grouping of water users working

46 D Feeny, et al. 1990. The tragedy of the commons - 22 years later. Human Ecology, v. 18, pp. 1-19. 
together towards a common goal. The main functions of the WUAs are to:

- prevent the misuse of water from the water source and waterworks (for example the irrigation channels);

- protect the water sources and waterworks;

- remove barriers unlawfully placed in the water source or in the waterworks;

- prevent any unlawful activity that may cause lower quality of the water source or water in the waterworks;

- act as custodians over the water source and the waterworks;

- investigate and take note of

O the amount of water in the water source and waterworks;

O the times and places where water is allowed to be used;

According to Mr. Stanley Chamberlain of the Upington Islands Water User Association, establishing a WUA requires that certain information that is necessary to complete a proposal has to be submitted to DWAF. ${ }^{47}$ This proposal must include the name of the proposed association and the area of jurisdiction. It can only be one area, which can be divided into sub-districts. A constitution for the proposed association must be composed according to the guidelines from the National Water Act No. 36 of 1998. An important aspect is that there must be proof of consultation and the inclusion of all interest groups (stakeholders). This proposal is then presented to the district office of DWAF in Kimberley where a committee decides if all requirements for a proposal were met. The district manager of the area involved then makes a recommendation and the proposal is sent to the DWAF head office in Pretoria.

Various directorates evaluate the proposal and a recommendation is made to the minister. An announcement is then made in the Government Gazette and any comments to the proposal need to be made within 60 days after publication. When no comments are given and all requirements were met, the minister will approve the proposal and the WUA can accept the proposal as their constitution. When this process is complete, a management committee must be elected from the ranks of water users, and the business plan must be developed with the proposed financial management plan. As is apparent in the interview with Mr Chamberlain, and confirmed by

47 S Chamberlain (Personal Collection), interview, CM Gouws, 29 July 2005. 
DWAF, ${ }^{48}$ the Act regulates the activities of the WUAs. A WUA may only exercise its functions and powers if it has been delegated by the CMA and the minister. The establishment of the WUAs is supposed to make the functions of the minister and CMAs easier by dealing with organised groupings rather than individual water users.

This proved to be a very difficult undertaking. As mentioned above, managing the commons means that restrictions must be put in place. This constitutes the tragedy of the commons, since individuals no longer have the freedom to freely relate to the water realm. Establishing management organisations, like a WUA, is a practical example of this theory. There are a few options, according to Mr. S. Chamberlain and his colleagues Messrs C Williams and C Erasmus, for the required procedures to follow in the establishment of WUAs and the issues they encountered along the way up to that specific time in the course of their dealings. ${ }^{49}$ Chamberlain, Williams and Erasmus are chief executive officers in charge of establishing WUAs in the LOCMA, the Upington Islands WUA being one of them.

By 2005 they had only begun the process and had already encountered several obstacles. The first was a human resource problem. DWAF employees were to be redeployed to the WUA. This redeployment took a long time. So, in the mean time, they worked for the WUA, but were still DWAF employees. It proved difficult to manage staff whose loyalties were somewhere else, especially where some of these employees were not happy with the redeployment to begin with. DWAF was still the employer but the WUA gave the orders. This confused everyone. Trade unions became involved and the situation became one of diplomacy and negotiating between the WUA and DWAF. Work towards affirming the WUA were pushed lower on the agenda. Employment conditions are the same for employees who are redeployed to the WUA, but in implementing these conditions, the WUA found that DWAF itself did not always implement these conditions to begin with. ${ }^{50}$

Another issue was the fact that the WUA came into existence in April 2001. DWAF was supposed to have a set of guidelines available to develop the WUA's business plan and constitution. The staff of the WUA only received these guidelines in 2005 , meaning that the process

48 Republic of South Africa. Department of Water Affairs and Forestry, Guide to the National Water Act (no. 36 of 1998)-Part 2: Water Management Strategies.........2006.

49 S Chamberlain, C Erasmus, C Williams, (Personal Collection), interview, CM Gouws, 29 July 2005.

50 S Chamberlain, C Erasmus, C Williams, (Personal Collection), interview, CM Gouws, 29 July 2005. 
was delayed by DWAF itself. ${ }^{51}$

Furthermore, communication appears to be a problem. Great effort is being put into arranging information sessions for stakeholders in the different municipalities, but executive members of the municipalities do not seem interested. This poses a substantial problem since every municipality must be represented on the management board of every WUA. Also, where municipalities are eager to participate, they sometimes insist on having all the members of a political party, in control of the council, to be on the management board. This highlights a misunderstanding regarding the functions of a management board of a WUA. Politics is not supposed to have any influence. A certain political party cannot have more say over the water resource because the National Constitution, No. 108 of 1996, the National Water Act, No. 36 of 1998 and ultimately the constitution of the particular WUA will ensure that all parties are allocated their fair share and pay for access to the resource accordingly. All these politicians do in the end, is to slow down the process. ${ }^{52}$ The moment management functions are politicised the core focus of managing the water commons gets lost in a tug of war between stakeholders, rather than protecting the resource. The intricacy of this issue warrants a separate article.

\section{The most explicit problems encountered by the UIWUA are:}

- The Upington Islands WUA is struggling with the billing system since DWAF insists on collecting the revenue from water users (mostly irrigators in and around Upington);

- The WUA is at a stage where they have sent the final draft of their constitution to the minister of DWAF. They have been waiting for a reply from the minister's office since November 2007;

- There is a conflict of interest between the representatives of the municipality and the irrigation farmers. Money allocated for issues of interest to the farmers during the time of the irrigation boards, are now made claim to by the municipality for other interests. This conflict of interest can become full blown conflict if not managed properly; and

51 Republic of South Africa. Department of Water Affairs and Forestry, Establishing a Catchment Management Agency, Guide 1 in the CMA/WUA series.....2005.

52 S Chamberlain, C Erasmus, C Williams, (Personal Collection), interview, CM Gouws, 29 July 2005. 
- The delays in establishing the LOCMA may have implications for the future functions of the UIWUA. The UIWUA will be officially established and fully operational by the time the LOCMA is established in 2011. Since the LOCMA will ultimately oversee the functions of the UIWUA, the LOCMA may change the operations of the UIWUA once it is established and this creates uncertainty with the management of the UIWUA.

\section{Conclusion}

When water is defined as a basic human right, should we then not be able to use this resource freely without laws and regulation? In his well-known response to this question, Hardin states that the population might show resistance to these restrictions since they take away certain freedoms. Only through the willingness to include those who do not currently enjoy this basic human right, can the problem pertaining to access to basic drinking water be successfully addressed. However, the right to water may never imply that water and its availability should be unrestricted.

South Africa has defined its National Water Act, No. 36 of 1998 and the National Water Resource Strategy in a response to these challenges. Both Act and Strategy are internationally respected as sound examples of well-defined water legislation and strategic management implementation plans. The legislation provides for the empowerment of all stakeholders, for self-regulating approaches in a new water policy environment and for strategies to make the plans succeed. Organisational structures such as the CMA and WUAs in the LOWMA, certainly would be able to deal with these matters in an exemplary manner.

The analysis provided in section five shows, however, that despite a promising legal framework, establishing the LOCMA and the UIWUA is a major challenge in practice. With regards to the LOCMA, public participation strategies failed in the beginning of the planned processes in 2002 and had to be re-initiated in 2007. Communication with the community proved to be a problem and retaining qualified personnel is still a challenge for this office of DWAF. These difficulties slowed the process of establishing the LOCMA down which lead to the DWAF head office setting up the new due date for the establishment of the LOCMA. Meanwhile the UIWUA started the process of developing a constitution for which they await a response from the minister. Establishing the UIWUA was fraught with practical uncertainties pertaining to the billing system and conflicts of interest between stakeholders. They had to deal with these difficulties with the support of certain individuals from the DWAF office and not with the support of an established LOCMA. The UIWUA officers also added to the sense of 
uncertainty in respect of the eventual involvement of the LOCMA once it was established. Since the UIWUA should be up and running by 2011, it might have to undergo changes in practices once the LOCMA is able to function as an organisation overseeing the business of the UIWUA.

These problems are serious indeed. In the case of the LOCMA and the UIWUA, any attempt to start solving these problems seems to boil down to one issue: how to find the personnel with the qualifications needed to give the institutions to be established a chance to succeed. A shift in the outlook on human resources is necessary for DWAF. The presence of Afrikaans speaking personnel, with a knowledge of the local resident and their requirements, are a prerequisite, especially where communication with the community needs to take place regularly. If effective communication with this redominantly rural community in the LOWMA fails, none of the processes needed to establish the LOCMA or performing the necessary functions in the UIWUA, will be possible. Employees must be able to make stakeholders water literate and to stimulate their interest to make their essential participation possible. This means that the priority has to be recruiting qualified officials, make sure remuneration is competitive with that of the private sector, and that the workload is manageable. This will ensure retention of qualified and experienced personnel.

How do we avoid the tragedies of the water commons? Avoiding management of the water commons is no longer possible since unrestricted access to this resource will surely lead to depletion. Avoiding the tragedy within the tragedy, however, with institutions responsible for managing the water commons not functioning the way they should, is avoidable but requires practical measures to avoid the tragedy within the tragedy. DWAF needs to ensure proper support for establishment of the LOCMA and the functions to be performed by the UIWUA. To accomplish this, DWAF must ensure that the human resources needed to adhere to the new timeline for establishment of the LOCMA, are qualified and experienced. 